\title{
Factors related occurrence of Haemonchosis of Goats in Rajshahi, Bangladesh
}

\author{
Nahar $\mathrm{L}^{1^{*}}$, Sarder $\mathrm{MJU}^{1}$, Mondal $\mathrm{MMH}^{2}$, Faruque $\mathrm{MO}^{2}$ and Islam $\mathrm{MH}^{1}$ \\ ${ }^{1}$ Department of Animal Husbandry \& Veterinary Science, Faculty of Agriculture, University of Rajshahi, \\ Bangladesh; ${ }^{2}$ Bangladesh Agricultural University, Mymenshingh, Bangladesh.
}

[Received: April 17, Accepted: August 16, 2012]

\begin{abstract}
The study was conducted on live and slaughtered goats in Rajshahi district during the period of March, 2011 to February, 2012 by coproscopy and necroscopy studies respectively. The aim of this study was to determine the factors such as age, sex and breed of the goat which influences the prevalence of haemonchosis. The information was collected from farmers through a questionnaire. A total of 720 goats examined, of which 416 goats were found positive for Haemonchus infection and the overall prevalence of haemonchosis in goat was $57.8 \%$. The prevalence rate was found to be higher in young ( $<2 \mathrm{yrs}), 63.8 \%$ compared to older $(>2 \mathrm{yrs}), 41.5 \%$ goats. It was observed that in relation to sex the prevalence of haemonchosis was higher in female, $63.9 \%$ compared to male, $50.0 \%$ goats. Among the breed, the crossbred goats were the maximum, $60.2 \%$ infection rate of haemonchosis than that of Black Bengal, $55.6 \%$ goats. The young stage and female goats are more prone to haemonchosis and statistically a significant difference $(P<0.05)$ was noted but there is no significant difference $(\mathrm{P}>0.05)$ was found in breed of goats. The present study suggests that young aged and females goats were more susceptible but crossbred goats were slightly susceptible to haemonchosis and requires special attention for its control.
\end{abstract}

Key words: Haemonchosis, age, sex, breed and Goat.

\section{INTRODUCTION}

Bangladesh is a subtropical country with subsistence agro-based economy. The agriculture of Bangladesh is almost entirely based on livestock. Livestock play an important role in the national economy of Bangladesh. Goat is a very important species of livestock in Bangladesh. There are about 24.15 million goats are found in Bangladesh ${ }^{\left[{ }^{1}\right.}$ ] .The landless and small farm holdings own the highest percentage of goats $\left[\begin{array}{ll}2 & ]\end{array}\right.$. Goat rearing is an economically important aspect of the agriculture sector, as most of the people live in rural areas ${ }^{[3]}$. The goat population in Bangladesh faces a lot of obstacles in the development due to their parasitic infestation specially haemonchosis is an important and common parasitic disease in goats and causes reduced weight gain and often mortality. Parasitic helminthes are a major cause of losses in productivity and health problems of goats and are associated with huge economic losses specially in resource poor regions of the world ${ }^{[4]}$. Haemonchosis caused by Haemonchus contortus and Haemonchus placei, is one of the most economically deteriorating disease of sheep and goats in Pakistan ${ }^{[5]}$. Infestation by Haemonchus contortus, which inhabits the fourth stomach (abomasum) in sheep and goat, is very high $(85 \%)$, mostly in young animals ${ }^{[6]}$. Haemonchosis causes anaemia, emaciation, and edema and gastric disturbances resulting principally from the loss of blood; heavy infection may be fatal. $H$. contortus are common blood feeders that cause low productivity, blood loss, and decrease in haemoglobin that can lead to death in heavily infected animals ${ }^{[7,8]}$. It has been estimated that each worm sucks about $0.05 \mathrm{ml}$ of bloods by seepage or ingestion from lesions per day ${ }^{[9] \text {. }}$

Nuruzzaman et $a l^{[10]}$ were observed prevalence of abomasal nematodes in relation to age, sex and breed of the goats. There was no statistically significant difference observed the risk factor sex in relation to the prevalence of abomasal nematodes in Bangladesh. However, there was statistically significant difference $(p<.001)$ observed among the risk factors (age and breed) in relation to the prevalence of Haemonchus contortus. Vlassoff et al ${ }^{\text {[ }}$ 11 ] demonstrated that the effect of helminthes infection on production of particular livestock species depend mostly up on the age of the animals, the breed, the parasite species involved and the intensity of the worm populations within the host. Tesfaheywet ${ }^{[12]}$ studied about the age and sex of the small ruminant affect the helminthosis in Ethiopia. Maqsood et al ${ }^{[5]}$ was studied haemonchosis with reference to breed, sex and age of sheep and goats in Pakistan.

However, no report so far has been published on the prevalence of haemonchosis in the present study areas, where goats are important assets to the local farmers. Hence, it is imperative to investigate the level of the Haemonchus infection and the associated risk factors such as age, sex and breed that make goats susceptible to the wide range of Haemonchus contortus in an area, in order to devise effective control measure and monitor their outcome properly. Therefore, it is the objective of this study to determine the prevalence and severity of haemonchosis, establish the relationship between 
Table 1.Prevalence of haemonchosis in goats by Examination type, age, sex and breed. collected samples were labeled with age, sex and breed of goat. The date of collection, the number of total and infected animals was also recorded.

\begin{tabular}{|c|c|c|c|c|}
\hline Factor & No.examined & No.positive & Prevalence $(\%)$ & $\begin{array}{l}\text { Chi-square test }(\chi 2) \\
\text { (P value) }\end{array}$ \\
\hline \multicolumn{5}{|c|}{ Examination type } \\
\hline Coproscopy & 363 & 182 & 50.1 & \multirow[t]{2}{*}{$17.52(0.000)$} \\
\hline Necroscopy & 357 & 234 & 65.5 & \\
\hline Total & 720 & 416 & & \\
\hline \multicolumn{5}{|l|}{ Age groups } \\
\hline Young(<2 yrs) & 527 & 336 & 63.8 & \multirow[t]{2}{*}{$28.81(0.000)$} \\
\hline Older(>2 yrs) & 193 & 80 & 41.5 & \\
\hline Total & 720 & & & \\
\hline \multicolumn{5}{|l|}{ Sex } \\
\hline Male & 316 & 158 & 50.0 & \multirow[t]{2}{*}{$13.97(0.000)$} \\
\hline Female & 404 & 258 & 63.9 & \\
\hline Total & 720 & & & \\
\hline \multicolumn{5}{|l|}{ Breed } \\
\hline Local & 378 & 210 & 55.6 & \multirow[t]{2}{*}{$1.611(.116)$} \\
\hline Cross-bred & 342 & 206 & 60.2 & \\
\hline Total & 720 & 416 & 57.8 & \\
\hline
\end{tabular}

factors influencing haemonchosis in goats in study area.

\section{MATERIALS AND METHODS}

\section{Study plan}

A cross- sectional study was done to detect the occurrence of parasitic disease in goats in Rajshahi during the period of March, 2011 to February, 2012. Goats were randomly selected from the nearby villages, pastures, veterinary hospitals and abattoirs. A questionnaire was prepared including information viz. name and address of farmer, type of sample, age, sex, and breed of goats for achievement of the study. A total of 720 goats were selected for the present study from which 363 for coproscopy and 357 for necropsy studies in the Rajshahi district. To achieve the goal selected goats were grouped according to the age, sex and breed. Sex of the goats were divided into two groups; female $(n=404)$ and male $(n=316)$ goats. Goats were categorized into two age groups as young animals of $<2$ years $(n=527)$ and olders of $>2$ years of age $(n=193)$. The age of goats were determined from birth register and examined by teeth and cornual ring reading. On the basis of breed characteristics and ancestor history goats were grouped into Black Bengal/local $(n=378)$ and crossbred $(n=342)$.

\section{Collection of sample}

In the coproscopy studies, faecal samples were collected by a two-finger procedure directly from the rectum of selected goats. Faecal samples were collected in $10 \%$ formalin containing suitable airtight containers, such as screw-cap bottles and plastic bags. At necropsy studies, abomasii were collected after slaughtering and evisceration of the goat in nearby slaughter houses in the study area. All the

\section{Examination procedure}

The monthly collection of faecal samples and abomasum were brought to the laboratory at the Department of Animal Husbandry and Veterinary Science, University of Rajshahi for the identification of Haemonchus spp. Faecal samples were examined by direct smear, floatation and sedimentation techniques for the presence of Haemonchus eggs. Haemonchus eggs were identified by using low power microscope according the keys and morphological characteristics ${ }^{[9]}$.

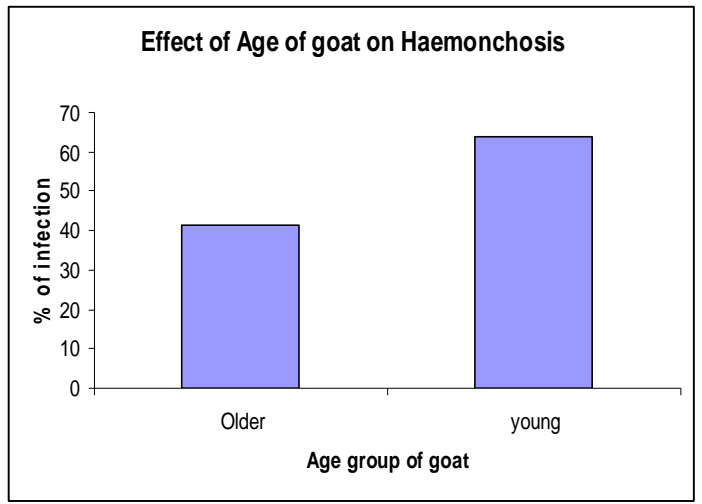

Fig-1; Effects of age of the goats in the percent of haemonchosis in the study area

Each abomasum was opened along the lesser curvature and the contents put in a plastic bucket. The mucosa was cleaned under running tap water and the washings drained into the bucket, and clean water was added to it to make the desired volume. After thorough stirring, the sedimented fluid was removed from the washings of the abomasum, into a container containing normal saline. The contents and washings of abomasii were inspected for the presence of mature and immature worms and 
Haemonchus spp was identified based on the characteristics given by ${ }^{[13] \text {. }}$

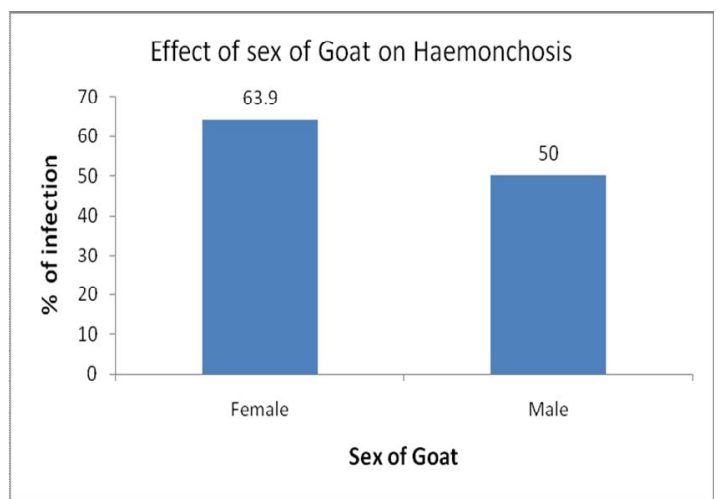

Fig-2; Effects of sex of the goats in the percent of haemonchosis in the study area

\section{Data analysis}

All the data that were collected (age, sex and breed) entered to MS excel sheet and analyzed by using SPSS version 19. Descriptive statistics was used to determine the prevalence of the haemonchosis and Chi-square test $\left(\chi^{2}\right)$ was used to look the significant difference between age, sex and breed of goats with haemonchosis. In all the analyses, confidence level was held at $95 \%$ and $\mathrm{P}<0.05$ were set for significance.

for 24 hours.

\section{RESULTS AND DISCUSSION}

The prevalence of haemonchosis of goats was studied for the evaluation of factors (age, sex and breed of goats) responsible for the occurrence of this disease in the study area. Overall prevalence of haemonchosis was $57.8 \%$ (416 out of 720) in examined goats which is in agreement with the findings of Nuruzzaman et al ${ }^{[10]}$ who reported $58 \%$ prevalence of Haemonchus contortus of goats in Thakurgaon district, Bangladesh. Amrita et al [14 ] was recorded as highest prevalence of Haemonchus in goats below one year of age and their overall prevalence rate was $45.13 \%$, and Bersissa et al ${ }^{[15]}$ found $39.4 \%$ Haemonchus contortus infection in Ethiopia which are dissimilar to the present study. Although the exact cause of dissimilarity in the prevalence of Haemonchus infection of goat cannot be explained but it may be associated with genetic and inheritable effect and to some extent managemental factors like grazing habit, rearing system, deworming status and study area etc.Among the examination pattern, coproscopy study was recorded $50.0 \%$ infection rate in which 184 faecal samples were positive out of 363 samples examined in live goat. In the necropsy Study, out of 357 abomasii, 234 samples were positive for Haemonchus worms, which was $65.5 \%$ of the infection in Slaughtered goat (Table-1) .This result is more closely related to the findings of
Shahiduzzaman ${ }^{[16]} 65.63 \%$ in slaughtered goat . Asif et al [ $\begin{array}{lll}{[} & 17 & \text { ] }\end{array}$ was found $75 \% \quad(252 / 120)$ Haemonchus infection recovered from faecal sample of goat in Pakistan. This controversy is might be due to the presence of sick animals, managemental effect, lack of using anthelmintics in the study area.

The graphical representation on prevalence of haemonchosis in different age group of goat is presented in Fig -1.Prevalence was higher in young aged $(63.8 \%)$ than adult aged goats. Maqsood et al ${ }^{[5}$ ] was found that the prevalence of haemonchosis was higher in goats less than two years of age $(47.8 \%)$ compared with those of above two years(33.3\%).

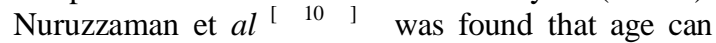
affect the occurrence of parasites. He also reported the prevalence of abomasal nematodes in goats were significantly $(p<0.01)$ higher in young aged $(84.61 \%)$ than adult aged $(61.21 \%)$ goats. Youngs were 3.30 times more susceptible than adults. The previous study found that the prevalence decreased as the age increased. Tesfaheywet ${ }^{[12]}$ was found $64.52 \%$ gastro-intestinal helminths in young and $56.29 \%$ in adult goats. These results are also related to the findings of $[18,19,20,21]$, those researchers reported that, prevalence of haemonchosis was higher in young goats due to the fact that with the advancement of age, vigor of the goats become better and they develop resistance against the parasitic diseases. The low level of parasitism reported in the adult animals is due to the development of significant immunity with the course of time ${ }^{[3]}$. It was also explained that the more infection in young goats is because of their low resistance or greater susceptibility due to the fact that these goats have not been exposed earlier in the infection. During the first year of their life they fed, grazed and browse on grasslands, thus the first stage of their exposure to infection with parasites occurs. Gradually, as the exposure to parasitic infection increases, the immune system of host animals builds up specially against Haemonchus spp and age resistance develops.

The effect of sex of goats on prevalence of haemonchosis is shown in Fig-2.According to sex, prevalence of haemonchosis in female goats was $63.09 \%$ (258/404) and in male was 50.0\% (158/306). Hassan et al ${ }^{[22]}$ gave almost similar findings, $57.49 \%$ in female and $42.51 \%$ in male goat in the Chittagong, Bangladesh. Maqsood et $a$ l $\left[{ }^{5]}\right.$ reported that the rate of haemonchosis was higher $(74.6 \%)$ in females than males $(59.1 \%)$. Shahiduzzaman et al ${ }^{[16]}$ reported that the infection rate of Haemonchus was significantly $(\mathrm{P}<0.05)$ higher in females than the male goats. Raza et al ${ }^{[23]}$ studied that incidence in female goat was $31.09 \%$ and male goat was $29.91 \%$. Saiful et al ${ }^{[24]}$, Qamar et al ${ }^{[25]}$ and Tesfaheywet ${ }^{[}$ 12] was observed higher rates of nematode infection in female hosts compared with the males. Higher prevalence of haemonchosis in females compared with males might be due to lowered resistance of female goats on the part of their reproductive events and unbalanced diet against higher needs and hench 
the females needs more nutrition for the nourishment of their kids they are voracious eaters by nature, which gives more chance of acquire of infective larvae than the males. Most of the researchers have observed higher rate of Haemonchus infection in female hosts compared with males; Maqsood et al ${ }^{[5]}$ Gauly et al ${ }^{[26]}$ studied that sex can influence the prevalence of helminthes. Vanimisetti et al ${ }^{[27]}$ have shown that, the females are stress during the pregnancy and lactation which helps for establishment of infection by the parasites. The present value of prevalence of haemonchosis is different from findings of Nuruzzaman et al ${ }^{[10]}$ observed that males was higher prevalence ( $65.22 \%$ ) than female $(51.85 \%)$ goats. Shahadat et al ${ }^{[28]}$ also reported the prevalence is higher in males than female goat. This was might be due to the study area, managemental effects, sample size, experimental design and deworming staus of the goats.

There was no statistically significant association between breed and prevalence of haemonchosis in goats (Table-1). The results showed that the prevalence of haemonchosis is higher in crossbred, $60.2 \%$ ( 206 out of 342 ) goats compared to local (Black Bengal), 55.6\% ( 210 out of 378) bred of goat. Nuruzzaman et $a l^{\text {[ ] }}$ observed that Black Bengal goats were comparatively higher (57.14\%) prvalence than cross-bred $(55.81 \%)$ goats in Thakurgaon district of Bangladesh.Those findings are almost similar to the present findings. This is due to the resistance of the Black Bengal goats against the Haemonchus infection. Goats which are browsers in their natural environment, the genetic pressure to develop resistance to Haemonchus contortus in the local breeds might be precluded. Genetic resistance operated mainly against worm establishment and that this was controlled by the immune response ${ }^{[16]}$.

\section{CONCLUSION}

The older aged, male goat and Black Bengal goats are slightly more resistant in prevalence of haemonchosis in Rajshahi district, Bangladesh. So, young aged, female and crossbred goats should be great care of management during grazing month on the pasture.

\section{ACKNOWLEDGEMENTS}

The authors are highly grateful to the Ministry of National Science and technology (NST) of Bangladesh for financial support in this research. The authors are very grateful to the Teachers and technical staffs of Department of Animal Husbandry and Veterinary Science under the University of Rajshahi for their kind cooperation during the study period. The researchers would like to extend the gratitude to the communal farmers for their cooperation and the Technicians of the farms for their assistance with faecal sample collection.

\section{REFERENCES}

1 BER(2011).Bangladesh Economic Review, Finance division, Ministry of Finance, Government of the People's Republic of Bangladesh, Dhaka.

2. Alam J and Aktaruzzaman (2010). Technical report on current and potential Market supply and Demand, marketing opportunities and consumer preferences for indigenous Breed Animals/products. FAnGR Asia Project on "Development \& Application of Decision Support Tools to Conserve \& Sustainably Use Genetic Diversity in Indigenous Livestock \& Wild Relatives" sponsored by ILRI, Nairobi, KENYA.

www.fangrasia.org/admin/admin_content/files/2 5588.

3. Tariq KA, Chishti MZ and Ahmad F (2010). Gastro-intestinal nematode infections in goats relative to season, host sex and age from the Kashmir valley, Indian Journal of Helminthology,84: 93-97.

4. Cernanska D, Varaday $\mathrm{M}$ and Corba J (2005).The occurrence of sheep gastrointestinal parasites in the Slovak Republic Helminthologia,42:205-209.

5. Maqsood M, Z. Iqbal and AH Chaudhary (1996. Prevalence and intensity of Haemonchosis with reference to breed, sex and age of sheep and goats. Pakistan Veterinary Journal, 16(1): 41-43

6. Rahaman, MH (2006). Banglapedia (National Encyclopedia of Bangladesh. www.banglapedia.org/httpdocs/HT/L_0115.HT ML

7. Githigia SM, Thamsborg SM, Munyua WK, Maingi N, (2001). Impact of gastro-intestinal helminthes on production in goats in Kenya. Small Ruminant Research. 42: 21-29.

8. Vatta AF, Letty BA, Van der Linde MJ,VanWijk EF, Hansen JW, and Krecek RC, (2001). Testing for clinical anaemia caused by Haemonchus spp. In goats farmed under resource-poor conditions in South Africa using an eye color chart developed for sheep, Veterinary Parasitology, 99: 1-14

9. Urquhart GM, Armour J, Duncan JL, Dunn AM and Jennings FW, (2000). Veterinary Parasitology, Blackwell Science Ltd. London.

10. Nuruzzaman $M$, Haque $M H$, Sarker $S$ and Begum N (2012). Abomasal nematodes in Goats Slaughtered at Different Abattoir of Thakurgaon District, Bangladesh, Journal of Scientific Rresearch,4 (2): 491-497). 
11. Vlasoff A, Leathwick DM, Heath ACG (2001). The epidemiology of nematode infections of sheep. New Zealand Veterinary Journal, 49: 213-221.

12. Tesfaheywet Z (2012). Helminthosis of sheep and goats in and around Haramaya, Southeastern Ethiopia, Journal of Veterinary Medicine and Animal Health, 4(3): 48-55.

13. Zajac MA and Conboy G (2006). Veterinary Clinical Parasitology. $7^{\text {th }}$ ed. Black Well Publishing Company. U.K.

14. Amrita S, Hazarika GC, Phukan A and Hussain P (2010). Seasonal incidence of Caprine Gastrointestinal Nematodosis, Veterinary World, 3(7): 321-322.

15. Bersissa K, Tadsse T, Sori T, Duguma $R$ and Hussen B (2011). Helminths of sheep and Goats in Central Oromia (Ethiopia) During the Dry Season, Journal of Animal and Veterinary Advances, 10(14):1845-1849.

16. Shahiduzzaman M, Alim MA, Rahman M and Mondal MMH (2003) Seasonal influence on the occurrence of Haemonchus contortus in slaughtered black Bengal goats in Bangladesh. Bangladesh journal of Veterinary Medicine 1:45-48.

17. Asif M, Azeem S, Asif S and Nazir S (2008). Prevalence of Gastrointestinal Parasites of Sheep and Goats in and around Rawalpindi and Islamabad, Pakistan. Journal of Veterinary and Animal Sciences, 1: 14-17.

18. Rizvi AR, Magrey TW and Zia EUH (1999).Clinical epidemiology and chemotherapy of haemonchosis in goats in Faisalabad, Pakistan. Journal of Faculty of Veterinary Medicine, University of Tehran, 54,107-109.

19. Magona JW, Musisi G (2002). Influence of age, grazing system, season and agroclimatic zone on the prevalence and intensity of gastrointestinal strongylosis in Ugandan goats. Small Ruminant Research. 44: 187-192.

20. Vanimisetti HB, Andrew SL, Zajac AM and Notter DR (2004). Inheritance of fecal egg count and packed cell volume and their relationship with production traits in sheep infected with Haemonchus contortus. Journal of Animal Science, 82:1602-1611.

21. Lateef M, Iqbal Z, Jabbar A, Khan MN and Akhtar MS, (2005). Epidemiology of trichostrongylid nematode infections in sheep under traditionalhusbandry system in Pakistan. International Journal of Agriculture and Biology, 7: 596-600.

22. Hassan MM, Hoque MA,. Islam SKMA, Khan SA, Roy K and Banu Q (2011). A prevalence of parasites in black bengal goats in Chittagong, Bangladesh. International Journal of Livestock Production,2(4):40-44.

23. Raza MA, Iqbala Z, Jabbara A. and Yaseena M. (2007). Point prevalence of gastrointestinal helminthiasis in ruminants in southern Punjab, Pakistan. Journal of Helminthology 81: 323328.

24. Saiful IKBM and Taimur MJFA (2008). Helminthic and protozoan internal parasitic infections in free ranging small ruminants of Bangladesh. Slovak Veterinary Research, 45 (2): 67-72.

25. Qamar MF, Maqbool A Khan KS, Ahmad N and Muneer MA (2007). Epidemiology of Haemonchosis in sheep and Goats under different managemental conditions.Veterinary World, 2(11):413-417

26. Gauly M, Schackert M, Hoffmann B, Erhardt $\mathrm{G}$, (2006). Influence of sex on the resistance of sheep lambs to an experimental Haemonchus contortus infection. Dtsch. Tierarztl. ochenschr. 113: 178-181.

27 .Vanimisetti HB, Andrew SL, Zajac AM and Notter DR (2004). Inheritance of fecal egg count and packed cell volume and their relationship with production traits in sheep infected with Haemonchus contortus. Journal of Animal Science, 82:1602-1611.

28. Shahadat MA, Karim MJ, Alam MZ, Majumder S, (2003): Seasonal distribution of Haemonchus contortus in Bengal goats. Bangladesh Veterinary Journal, 20:72-76. 